\title{
PEWARNAAN SIMPUL, SISI, WILAYAH PADA GRAF DAN PENERAPANNYA
}

\author{
Afriantini, Helmi, Fransiskus Fran
}

\section{INTISARI}

Pewarnaan graf merupakan pemetaan warna-warna pada unsur graf. Terdapat 3 jenis pewarnaan yang digunakan pada pewarnaan graf yaitu pewarnaan simpul, pewarnaan sisi, dan pewarnaan wilayah. Pewarnaan graf dapat diterapkan untuk menyelesaikan masalah pada penjadwalan, pewarnaan peta, penugasan, dan lain sebagainya. Algoritma penyelesaian pada pembahasan pewarnaan graf ini menggunakan Algoritma Welch-Powell yaitu dengan mengurutkan simpul secara menurun berdasarkan derajat simpulnya dan mengurutkan sisi sesuai urutan jumlah sisi yang terhubung. Selanjutnya warnai simpul yang memiliki derajat tertinggi. Setelah simpul dengan derajat tertinggi diwarnai, maka warnai dengan warna yang berbeda simpul berikutnya sesuai urutan derajat namun yang bertetangga dengan simpul yang telah diwarnai. Pewarnaan wilayah diselesaikan dengan menggunakan konsep pewarnaan simpul. Jadwal pembagian loker pada suatu kantor babysitter diselesaikan menggunakan pewarnaan simpul, pembagian shift kerja paling efisien pada pabrik reparasi mobil diselesaikan menggunakan pewarnaan sisi, serta peta dan pemetaan pembangunan desa strategis di Kecamatan Tekarang, Kabupaten Sambas, Kalimantan Barat diselesaikan menggunakan pewarnaan wilayah. Dari hasil penelitian diperoleh bahwa dari 8 orang anak yang dititipkan di kantor babysitter, diperlukan setidaknya 5 loker untuk diberikan kepada orangtua sesuai jadwal. Shift kerja minimum yang dibutuhkan untuk menyelesaikan reparasi 8 mobil dalam waktu satu pekan dengan 3 pos reparasi adalah 7 shift. Jumlah minimum warna yang diperlukan untuk mewarnai peta Kecamatan Tekarang adalah 3 warna, serta desa yang memiliki letak strategis yang perlu didahulukan untuk pembangunan daerah adalah Desa Sari Makmur dan Desa Sempadian.

Kata Kunci : pewarnaan graf, penjadwalan, pewarnaan peta.

\section{PENDAHULUAN}

Matematika diskrit merupakan salah satu cabang matematika yang mengkaji tentang objek-objek diskrit. Salah satu bahasan dalam matematika diskrit adalah teori graf. Teori graf muncul pertama kali pada tahun 1736, yakni ketika seorang matematikawan Swiss bernama Leonhard Euler berhasil menyelesaikan permasalahan yang sangat terkenal yaitu Jembatan Königsberg. Masalah jembatan Königsberg adalah apakah mungkin untuk melewati tujuh jembatan hanya tepat satu kali dan akan kembali lagi ke tempat semula. Leonhard Euler adalah orang pertama yang berhasil menemukan jawaban masalah tersebut dengan memodelkan masalah ke dalam bentuk graf.

Salah satu topik menarik dari teori graf yaitu pewarnaan graf (graph colouring). Pada pewarnaan graf terdapat 3 jenis pewarnaan yaitu pewarnaan simpul, pewarnaan sisi, dan pewarnaan wilayah, dan ketiga topik ini terus mengalami perkembangan.

Pewarnaan pada graf $G$ adalah pemetaan warna-warna pada simpul, sisi, atau wilayah pada graf $G$ sedemikian sehingga setiap simpul, sisi, atau wilayah yang bertetangga mempunyai warna yang berbeda. Graf $G$ dikatakan berwarna $n$ jika terdapat pewarnaan dari $G$ yang menggunakan sebanyak $n$ warna. Pada pewarnaan simpul dan wilayah, jumlah warna minimum yang dapat digunakan untuk mewarnai suatu graf $G$ disebut bilangan kromatik (chromatic number), yang dinotasikan dengan $\chi(G)$. Pada pewarnaan sisi, jumlah warna minimum yang dapat digunakan untuk mewarnai suatu graf $G$ disebut indeks kromatik (chromatic index), yang dinotasikan dengan $\chi^{\prime}(G)$. Suatu graf $G$ mempunyai bilangan kromatik $k$ ( $k$-chromatic) jika $\chi(G)=k$ atau $\chi^{\prime}(G)=k$.

Pewarnaan graf banyak digunakan untuk menyelesaikan masalah penjadwalan atau scheduling. Untuk menyelesaikan masalah penjadwalan dalam graf, dapat digunakan algoritma penyelesaian [1]. Salah satu algoritma penyelesaian pewarnaan graf adalah algoritma Welch-Powell. Algoritma Welch-Powell 
merupakan salah satu algoritma pewarnaan graf yang melakukan pewarnaan berdasarkan derajat tertinggi dari simpulnya (pewarnaan simpul) dan banyaknya sisi yang terhubung (pewarnaan sisi). Langkah pertama dalam algoritma Welch-Powell adalah mengurutkan simpul dan sisi dari $G$ dalam derajat yang menurun. Selanjutnya gunakan satu warna untuk mewarnai simpul atau sisi pertama (yang mempunyai derajat tertinggi). Setelah mewarnai simpul atau sisi pertama, dilanjutkan dengan memberi warna yang berbeda pada simpul atau sisi lain menurut urutan derajat namun yang bertetangga dengan simpul atau sisi pertama yang telah diberi warna. Selanjutnya mulai lagi dengan simpul atau sisi berderajat tertinggi lainnya, dan terakhir ulangi penggunaan warna-warna sampai semua simpul atau sisi terwarnai [2].

Pewarnaan wilayah biasanya digunakan untuk pewarnaan peta dan menemukan permasalahan terkait pemetaan daerah di suatu kabupaten atau kota. Wilayah pada peta direpresentasikan sebagai ruang atau wilayah dalam graf. Jika wilayah telah terbentuk menjadi suatu graf, maka wilayah-wilayah tersebut dibentuk menjadi graf planar. Selanjutnya, graf planar dibentuk menjadi graf dual dengan cara setiap ruang atau wilayah menjadi sebuah simpul. Oleh karena wilayah-wilayah telah diwakili oleh simpul, maka untuk penggunaannya dapat menggunakan algoritma pewarnaan simpul. Setelah graf dual diwarnai, warna dapat dikembalikan ke peta awal kembali [3].

Pada penelitian ini dikaji pewarnaan simpul, pewarnaan sisi, pewarnaan wilayah pada graf khususnya graf sederhana dan graf terhubung. Lebih lanjut, dibahas pula penerapan pewarnaan simpul, sisi, dan wilayah pada kasus yang sesuai. Misal diberikan suatu kasus dengan pewarnaan sim pul. Untuk menyelesaikan kasus ini, objek-objek yang ada direpresentasikan sebagai sebuah simpul. Simpul-simpul yang ada dihubungkan dengan suatu sisi yang merepresentasikan hubungan antar simpul. Selanjutnya, urutkan simpul yang memiliki derajat tertinggi ke yang terendah. Simpul yang memiliki derajat tertinggi diwarnai terlebih dahulu, dilanjutkan dengan memberi warna yang berbeda pada simpul yang bertetangga dengan simpul yang sudah diwarnai. Pewarnaan sisi memiliki algoritma yang sama dengan pewarnaan simpul, yaitu dengan terlebih dahulu memberi warna pada sisi yang bertetangga dengan simpul berderajat tertinggi. Pewarnaan wilayah biasanya digunakan untuk pewarnaan peta. Wilayah pada peta direpresentasikan sebagai ruang atau wilayah dalam graf. Jika wilayah telah terbentuk menjadi suatu graf, maka wilayah-wilayah tersebut dibentuk menjadi graf planar. Selanjutnya, graf planar dibentuk menjadi graf dual dengan cara setiap ruang atau wilayah menjadi sebuah simpul.

\section{PEWARNAAN GRAF}

Suatu graf $G$ terdiri dari dua himpunan yang berhingga, yaitu himpunan titik-titik tidak kosong yang disimbolkan dengan $V(G)$ dengan elemen-elemennya disebut simpul dan himpunan garis-garis yang disimbolkan dengan $E(G)$ dengan elemen-elemennya disebut sisi [4]. Pewarnaan pada graf $G$ adalah pemetaan warna-warna pada simpul, sisi, atau wilayah pada graf $G$ sedemikian sehingga setiap simpul, sisi, atau wilayah yang bertetangga mempunyai warna yang berbeda. Pewarnaan simpul dan pewarnaan wilayah memiliki jumlah warna minimum yang disebut dengan bilangan kromatik dan pewarnaan sisi memiliki jumlah warna minimum yang disebut dengan indeks kromatik.

Definisi 1 [5] Bilangan kromatik graf $G$ adalah jumlah warna minimum yang dapat digunakan untuk mewarnai suatu graf. Suatu graf $G$ mempunyai bilangan kromatik $k$ ( $k$ - chromatic) jika $\chi(G)=k$.

Pada pewarnaan simpul dan wilayah, bilangan kromatik dinotasikan dengan $\chi(G)$, sedangkan pada pewarnaan sisi, indeks kromatik dinotasikan dengan $\chi^{\prime}(G)$.

\section{PEWARNAAN SIMPUL PADA GRAF}

Berikut diberikan definisi pewarnaan simpul beserta kasus penerapannya pada penentuan jadwal pembagian loker di kantor babysitter. 
Definisi 2 [5] Pewarnaan simpul pada graf $G$ adalah pemberian warna pada simpul-simpul di graf $G$ sedemikian sehingga setiap dua simpul yang bertetangga (terhubung langsung) memiliki warna yang berbeda.

Berdasarkan Definisi 2, diberikan contoh pewarnaan simpul pada graf.

Contoh 3 Diberikan graf $A$ dengan himpunan simpul $V(A)=\left\{v_{1}, v_{2}, v_{3}, v_{4}\right\}$ dan himpunan sisi $E(A)=\left\{\left(v_{1}, v_{2}\right),\left(v_{2}, v_{3}\right),\left(v_{3}, v_{4}\right),\left(v_{1}, v_{4}\right),\left(v_{1}, v_{3}\right)\right\}$

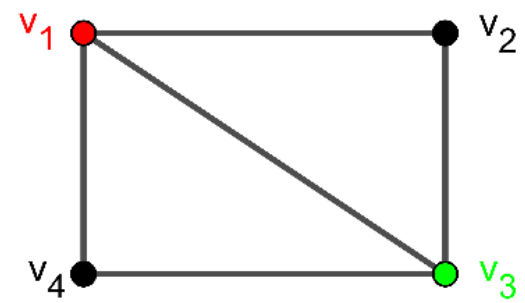

\section{Gambar 1 Pewarnaan simpul Graf $\boldsymbol{A}$ dengan 3 warna}

Contoh 4 Sebuah kantor babysitter mendapatkan titipan 8 orang anak untuk dijaga. Misalkan inisial anak-anak tersebut adalah $A, B, C, D, E, F, G$ dan $H$. Setiap anak tidak berada setiap waktu di kantor, anak-anak datang dan pergi sesuai waktu pesanan oleh orangtuanya. Oleh karena itu, penjaga kantor perlu menentukan jadwal pembagian loker kepada orangtua anak sehingga didapatkan seminimal mungkin loker yang perlu disediakan. Tabel jadwal pesanan dari orangtua sebagai berikut.

Tabel 1 Jadwal penitipan anak

\begin{tabular}{|l|c|c|c|c|c|c|c|c|}
\hline Waktu & $\mathrm{A}$ & $\mathrm{B}$ & $\mathrm{C}$ & $\mathrm{D}$ & $\mathrm{E}$ & $\mathrm{F}$ & $\mathrm{G}$ & $\mathrm{H}$ \\
\hline 07.00 & $*$ & $*$ & - & - & $*$ & - & - & - \\
\hline 08.00 & - & $*$ & $*$ & - & - & $*$ & $*$ & - \\
\hline 09.00 & - & $*$ & $*$ & $*$ & - & $*$ & - & $*$ \\
\hline 10.00 & - & $*$ & - & $*$ & - & - & - & $*$ \\
\hline 11.00 & - & $*$ & - & - & - & - & $*$ & $*$ \\
\hline 12.00 & $*$ & $*$ & - & - & $*$ & - & - &
\end{tabular}

Adapun langkah menyelesaikan masalah di atas sesuai dengan pengaplikasian pada pewarnaan simpul pada graf adalah sebagai berikut.

1. Menggambar simpul graf

Simpul graf dibuat berdasarkan banyaknya anak yang dititipkan.
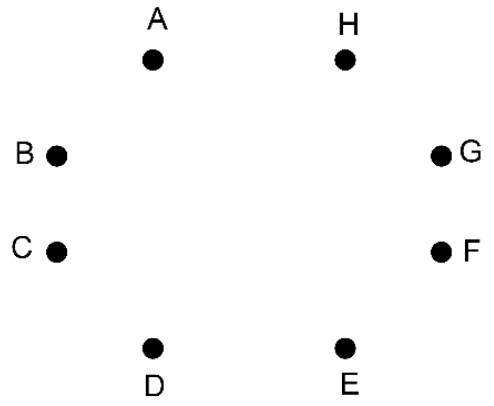

Gambar 2 Simpul-simpul yang merepresentasikan anak 
2. Menggambar sisi pada graf

Sisi direpresentasikan pada anak yang mempunyai waktu yang sama saat berada di kantor babysitter.

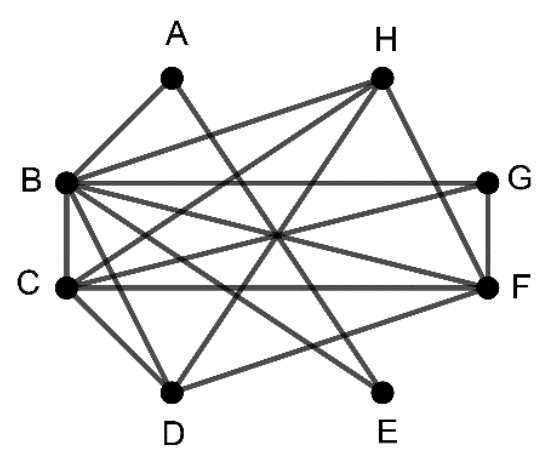

Gambar 3 Graf yang merepresentasikan hubungan jadwal untuk setiap anak

3. Mewarnai graf

Setelah dibuat simpul dan sisi, maka selanjutnya simpul graf diwarnai dengan minimum warna yang mungkin menggunakan teori pewarnaan simpul.

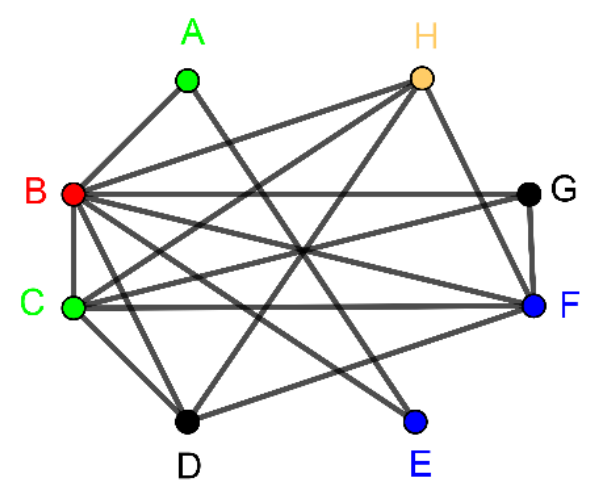

Gambar 4 Graf yang telah diwarnai

Warna paling minimum yang bisa diberikan pada graf di atas sebanyak 5 buah warna. Akibatnya, pada kasus loker yang dibagikan kepada 8 orangtua anak, minimum loker yang perlu disediakan adalah sebanyak 5 loker. Diberikan himpunan $\{1,2,3,4,5\}$ dimana merah $=$ loker 1 , biru $=$ loker 2 , hijau $=$ loker 3, hitam $=$ loker 4, dan kuning $=$ loker 5. Maka, dengan demikian anak $B$ diberikan loker 1 , anak $E$ dan $F$ diberikan loker 2, anak $C$ dan $A$ diberikan loker 3, anak $G$ dan $D$ diberikan loker 4, dan anak $H$ diberikan loker 5 .

\section{PEWARNAAN SISI PADA GRAF}

Berikut diberikan definisi pewarnaan sisi beserta kasus penerapannya pada open shop scheduling.

Definisi 5 [5] Pewarnaan sisi pada graf $G$ adalah pemberian warna pada sisi-sisi di graf $G$ sedemikian sehingga setiap dua sisi yang bertetangga (terhubung langsung) memiliki warna yang berbeda.

Berdasarkan Definisi 5, diberikan contoh pewarnaan sisi pada graf. 
Contoh 6 Diberikan Graf $B$ dengan himpunan simpul $V(B)=\left\{v_{1}, v_{2}, v_{3}, v_{4}\right\}$ dan himpunan sisi $E(B)=\left\{e_{1}, e_{2}, \ldots, e_{6}\right\}$

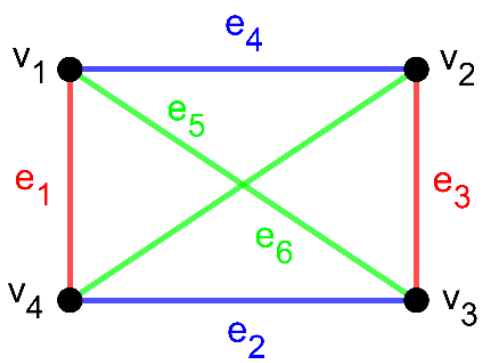

Gambar 5 Pewarnaan sisi Graf $B$ dengan 3 warna

Contoh 7 Sebuah pabrik reparasi mobil menerima 8 buah mobil rusak yang harus direparasi. Pos reparasi hanya tersedia sebanyak 3 pos, sedangkan waktu yang digunakan untuk menyelesaikan proses perbaikan mobil hanya diberikan satu pekan. Oleh karena itu, dicari berapa banyak shift yang bisa dibuat oleh pabrik untuk bisa menyelesaikan perbaikan 8 buah mobil dalam waktu sepekan. Adapun langkah menyelesaikan masalah di atas sesuai dengan pengaplikasian pada pewarnaan sisi pada graf adalah:

1. Menggambar sisi dan simpul pada graf

Simpul $A, B, \ldots, H$ direpresentasikan sebagai jumlah mobil yang rusak dan diperbaiki, sedangkan simpul $R_{1}, R_{2}, R_{3}$ merepresentasikan 3 pos yang tersedia.

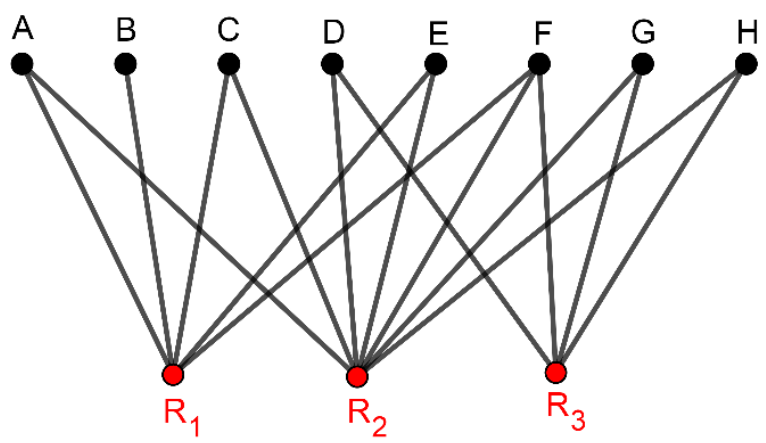

Gambar 6 Skema jadwal reparasi pabrik mobil yang dipresentasikan dalam graf

Setelah sistem kerja pabrik reparasi mobil direpresentasikan ke dalam bentuk graf di atas, selanjutnya ditentukan pembagian jadwal penggunaan tiap tempat untuk masing-masing mobil. Pembagian jadwal di sini dibuat dalam bentuk kerja shift. Cara pelaksanaannya adalah dengan menggunakan konsep pewarnaan sisi pada graf.

2. Mewarnai Graf

Diasumsikan bahwa setiap pos reparasi hanya bisa menerima satu mobil pada satu shift dan proses reparasi mobil pada tiap pos akan memakan waktu yang relatif sama. Misalkan dimulai dari jadwal mobil $B$ pada pos $R_{1}$. Pada sisi tersebut diberikan label $a$ yang merupakan shift kerja pertama hari pertama. Diasumsikan pula bahwa shift bekerja dapat berubah sesuai keadaan, namun suatu pekerjaan yang dilakukan pada shift tersebut harus terlebih dahulu diselesaikan sebelum melanjutkan pergantian shift. Selanjutnya, labeli sisi pada jadwal mobil $A$ pada pos $R_{1}$. Dikarenakan pos pada $R_{1}$ bersisian atau bertetangga dengan sisi yang telah dilabeli $a$, maka sisi ini akan diberi label $b$ yang merupakan shift kerja kedua. Namun, pada jadwal mobil $A$ di pos $R_{2}$, karena kedua simpul tidak bertetangga dengan yang telah dilabeli $a$, maka dapat dilabeli kembali dengan label $a$ yang berarti bahwa mobil $A$ mempunyai jadwal reparasi di pos $R_{2}$ pada shift 
pertama, kemudian di pos $R_{1}$ pada shift selanjutnya. Hal yang sama dilakukan pada jadwal reparasi mobil $B$. Pada sisi pertama, yang bertetangga dengan simpul $R_{1}$ dan $R_{2}$, maka sisi ini dilabeli $c$, karena pada simpul di $R_{1}$, telah ada yang dilabeli $a$ dan label $b$. Selanjutnya dilakukan metode yang sama sehingga didapatkan warna minimum sebanyak 7 warna dari 16 sisi yang ada dengan menggunakan algoritma seperti di atas, dari kasus ini graf akhir yang didapatkan sebagai berikut.

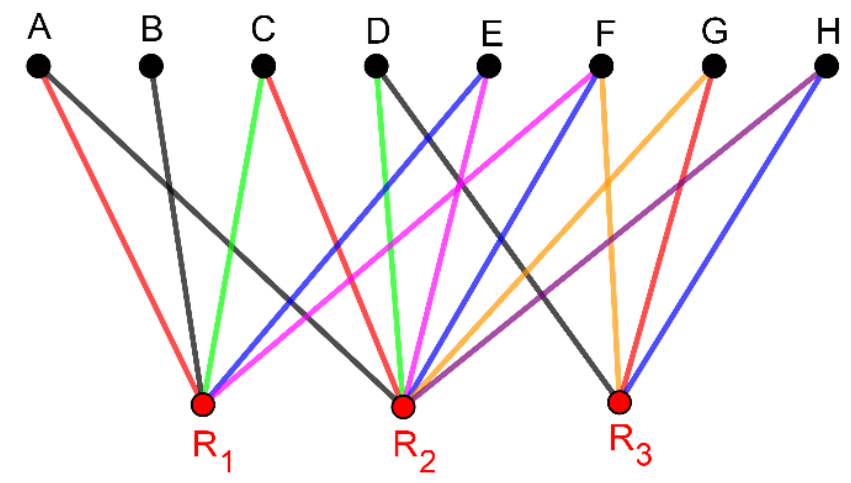

Gambar 7 Graf representasi jadwal reparasi mobil yang telah dilabeli dan diwarnai

Dengan demikian, dapat disimpulkan bahwa dari 8 buah mobil klien pabrik yang direparasi dalam satu pekan, dibutuhkan paling sedikit 7 shift kerja pada 3 pos reparasi.

\section{PEWARNAAN WILAYAH PADA GRAF}

Berikut diberikan definisi pewarnaan wilayah beserta kasus penerapannya pada pewarnaan peta Kecamatan Tekarang, Kabupaten Sambas.

Definisi 8 [5] Pewarnaan wilayah pada graf $G$ adalah pemberian warna pada wilayah di graf $G$ sedemikian sehingga setiap dua wilayah yang bertetangga (terhubung langsung) memiliki warna yang berbeda.

Dari Definisi 8, diberikan contoh pewarnaan simpul pada graf

Contoh 9 Diberikan Graf $P$ dengan himpunan wilayah $R=\left\{r_{1}, r_{2}, \ldots, r_{6}\right\}$

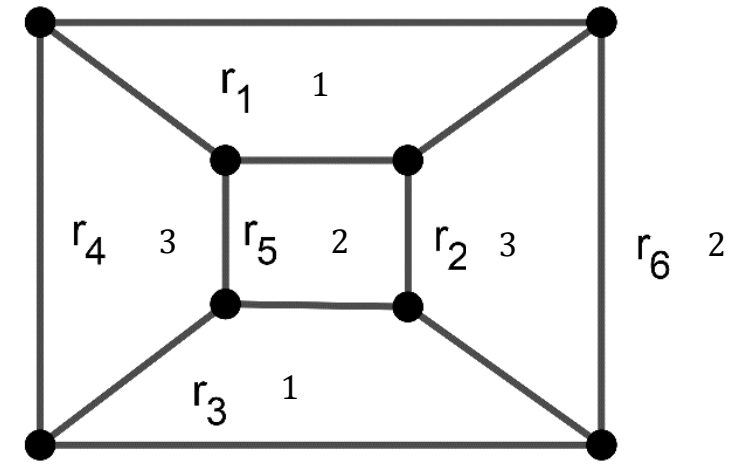

\section{Gambar 8 Graf $P$ pewarnaan wilayah dengan 3 warna}

Khusus pada pewarnaan wilayah, peta atau wilayah yang diwarnai atau diselesaikan masalahnya harus dibentuk menjadi graf planar terlebih dahulu. Graf planar adalah graf yang dapat digambarkan pada bidang datar sedemikian sehingga tidak ada sisi-sisinya yang saling berpotongan. Setelah dibentuk ke graf planar, selanjutnya dibentuk menjadi graf dual dimana setiap ruang dalam wilayah di graf planar dijadikan sebagai sebuah simpul, dan simpul-simpul yang bertetangga dihubungkan oleh sebuah sisi. Dengan demikian, pewarnaannya menggunakan konsep pewarnaan simpul. 
Contoh 10 Kecamatan Tekarang merupakan salah satu kecamatan yang ada di Kabupaten Sambas, Provinsi Kalimantan Barat. Kecamatan ini adalah salah satu kecamatan yang sedang berkembang, maka untuk mendukung perkembangan, diperlukan persiapan yang matang. Persiapan tersebut dapat dimulai dari SDM (Sumber Daya Manusia), peralatan, maupun analisa wilayah. Proses transformasi setiap kecamatan, kota atau kabupaten biasanya diawali oleh bergabungnya kota-kota atau daerah yang berdekatan. Melalui pemilihan pusat kecamatan yang strategis, maka diharapkan pengembangan daerah pada setiap desa akan relatif sama. Kecamatan Tekarang memiliki 7 desa. Maka jumlah sisi yang digunakan adalah 7 simpul. Jika antar desa saling berbatasan, maka ada 2 simpul yang akan bertemu, yang disebut sisi. Desa yang memiliki sisi paling banyak diasumsikan merupakan desa strategis, karena merupakan desa yang paling banyak berbatasan langsung dengan desa lainnya. Pengembangan kecamatan seharusnya dimulai dari desa strategis ini. Berikut diberikan peta Kecamatan Tekarang beserta desanya yang disajikan pada Gambar 9 [6]

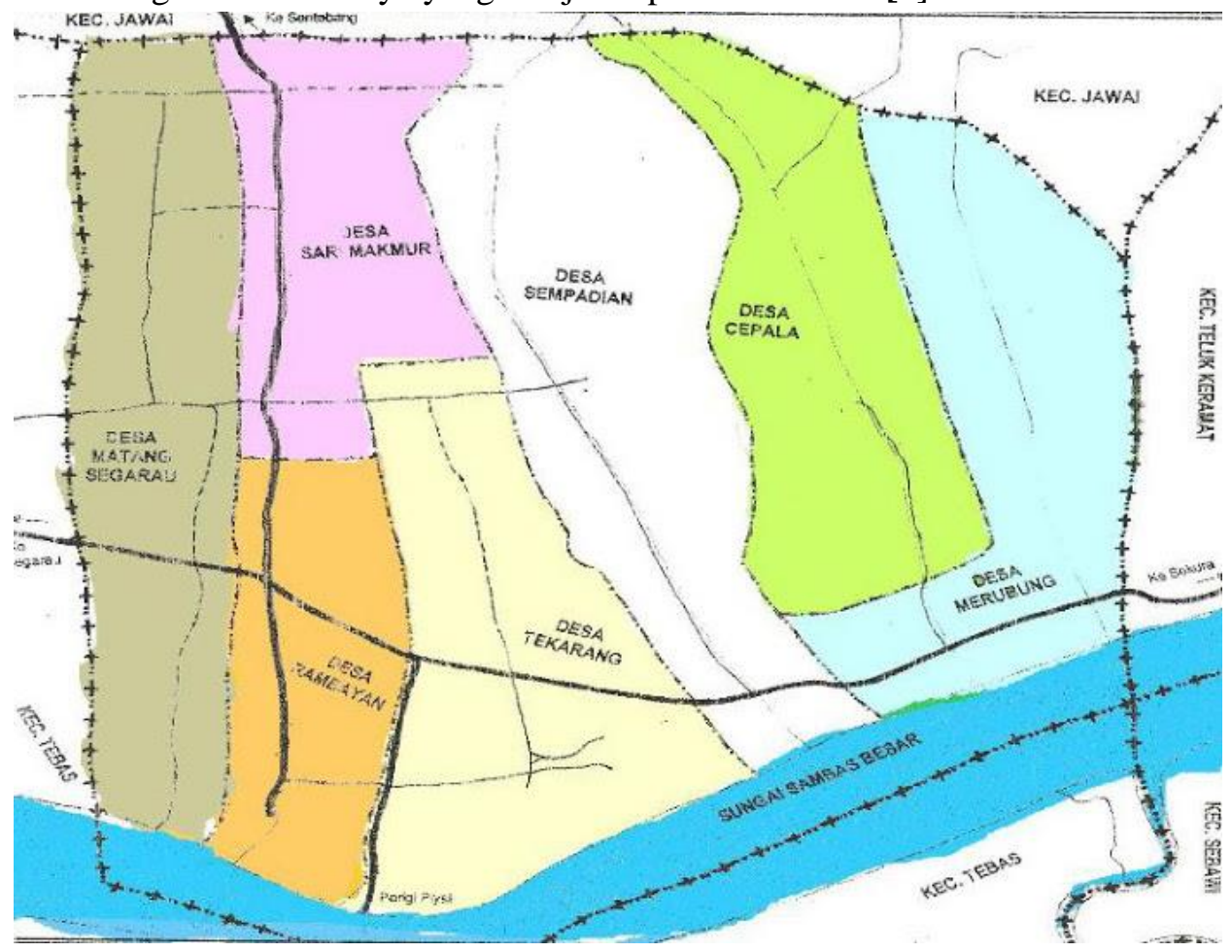

Gambar 9 Peta Kecamatan Tekarang

Dari peta ini dibuat menjadi graf planar. Berikut disajikan graf planar dari peta wilayah Kecamatan Tekarang pada Gambar 10.

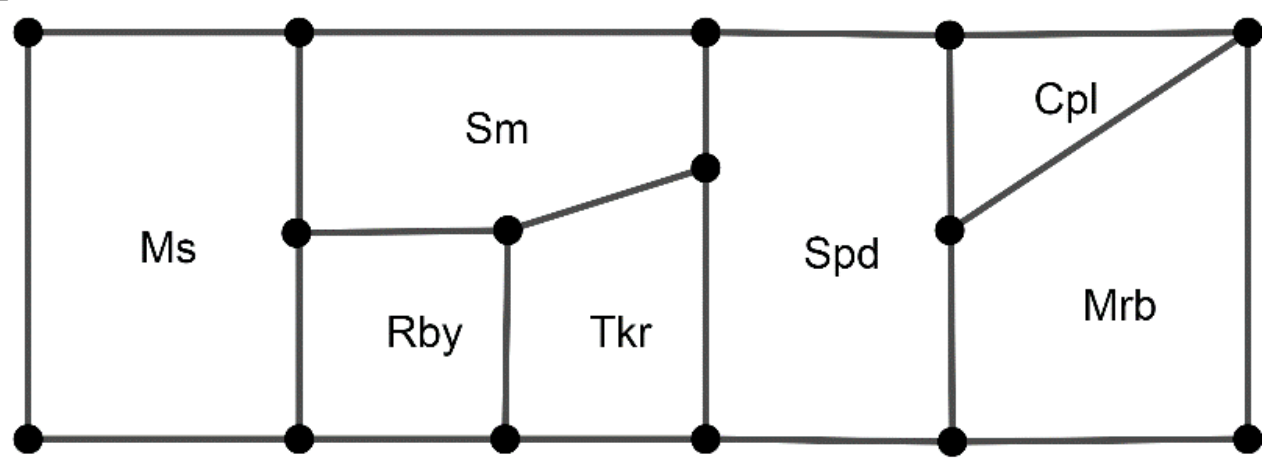

Gambar 10 Graf Planar dari Peta wilayah Kecamatan Tekarang 
Selanjutnya, dari graf planar dibentuk menjadi graf dual, dimana setiap desa direpresentasikan sebagai simpul dan desa-desa yang berdampingan direpresentasikan sebagai sisi. Berikut disajikan graf dual dari graf planar pada Gambar 11.

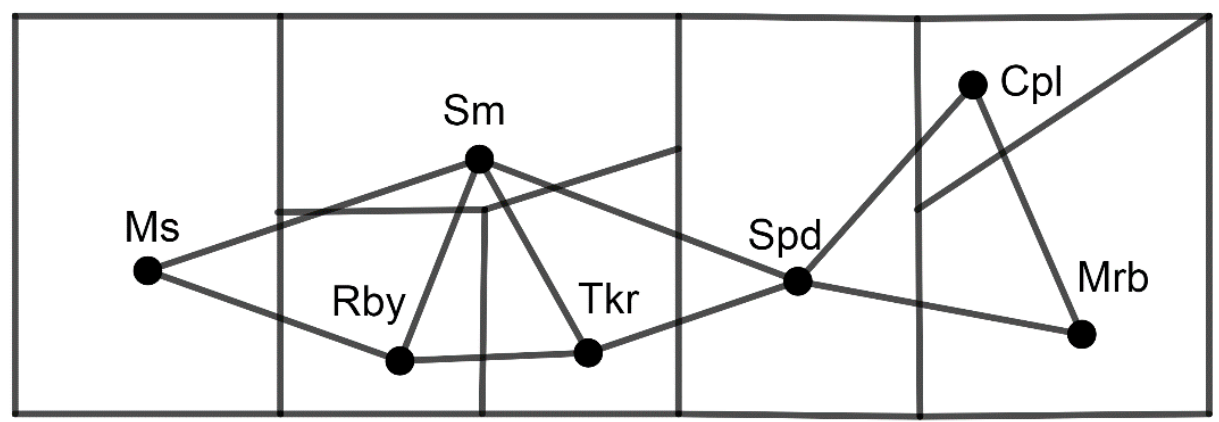

\section{Gambar 11 Graf Dual dari Peta wilayah Kecamatan Tekarang}

Lebih lanjut, yang dilakukan adalah mengurutkan derajat simpul yang tertinggi ke yang terendah. Dari graf di atas diperoleh bahwa Desa Sari Makmur dan Desa Sempadian memiliki degree yang paling banyak yaitu 4 . Dengan demikian, kedua desa ini memiliki letak wilayah yang strategis dibandingkan desa lainnya. Selanjutnya, dilakukan pewarnaan pada peta dengan cara mencari bilangan kromatik dari graf dual yang telah terbentuk. Simpul (desa) dengan derajat tertinggi terlebih dahulu diberi warna, setelah itu, simpul yang bertetangga dengannya harus diberi warna yang berbeda. Selanjutnya dilakukan dengan cara yang sama sehingga dari graf dual diperoleh bahwa jumlah warna untuk pewarnaan peta desa di Kecamatan Tekarang adalah sebanyak 3 warna.

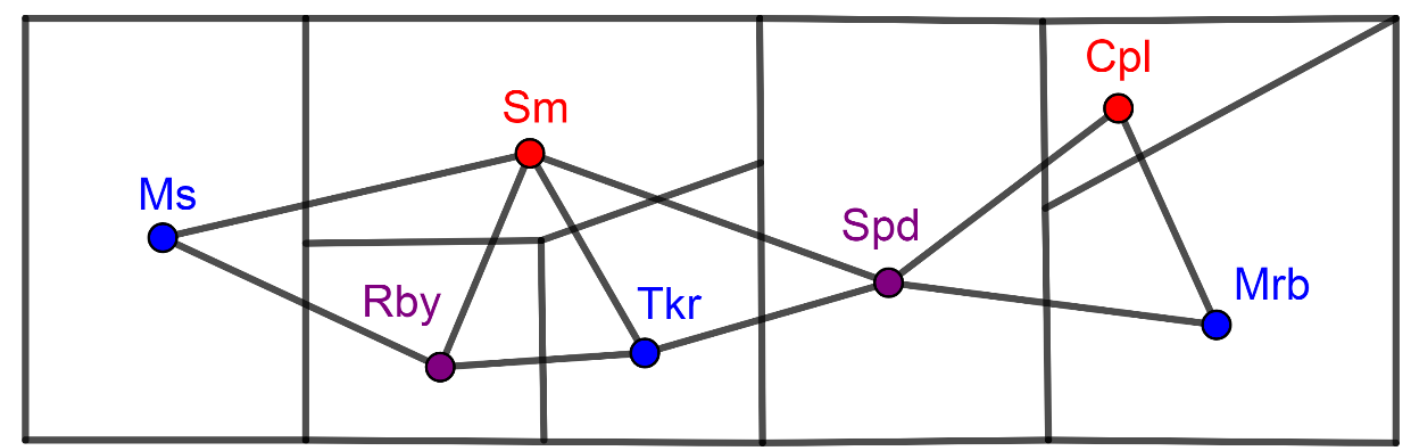

\section{Gambar 12 Graf Dual 3 warna peta wilayah Kecamatan Tekarang}

Berdasarkan Gambar 12, diperoleh bahwa peta wilayah Kecamatan Tekarang yang terdiri dari 7 desa dapat diwarnai setidaknya 3 warna. Desa Sari Makmur dan Desa Cepala diwarnai merah, Desa Matang Segarau, Desa Tekarang dan Desa Merubung diwarnai biru, Desa Rambayan dan Desa Sempadian diwarnai ungu. Pada Gambar 13 berikut ini adalah peta Kecamatan Tekarang yang diwarnai dengan 3 warna yang diperoleh dari pewarnaan graf. 


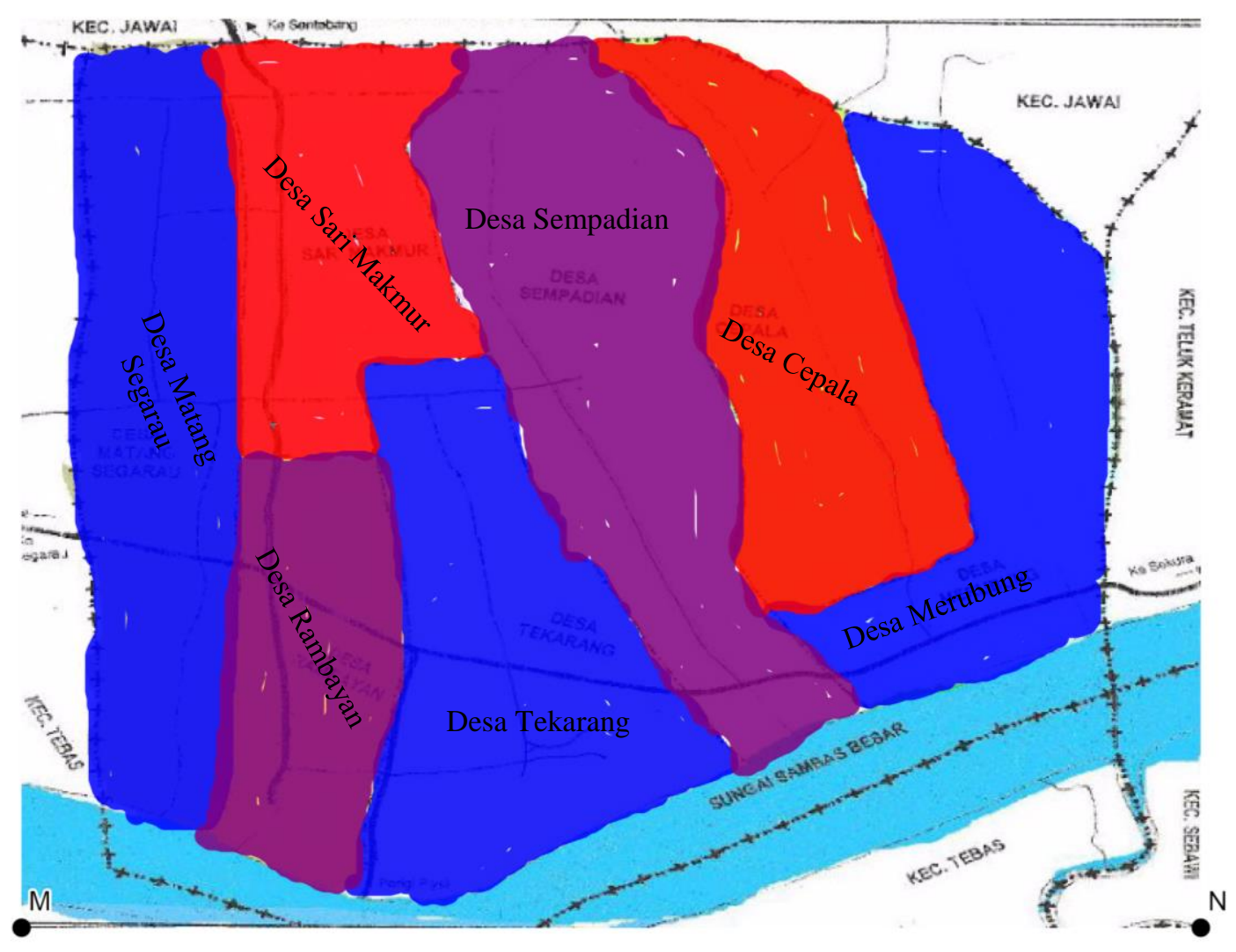

\section{Gambar 13 Peta Kecamatan Tekarang yang diwarnai dengan 3 warna}

Berdasarkan pewarnaan wilayah yang didapatkan dari graf dual, desa-desa di Kecamatan Tekarang diwarnai dengan minimum 3 warna. Gambar 12 menggambarkan graf dual peta yang masih mewarnai simpul-simpulnya, sedangkan pada Gambar 13, warna telah diberikan pada peta sehingga peta dapat diwarnai dengan warna yang telah ditentukan. Sama halnya dengan warna pada graf dual, peta juga diwarnai dengan Desa Sari Makmur dan Desa Cepala diwarnai merah, Desa Matang Segarau, Desa Tekarang dan Desa Sempadian diwarnai biru, Desa Rambayan dan Desa Sempadian diwarnai ungu. Selain itu, dengan menggunakan konsep pewarnaan simpul yang dibuat dari graf dual, diperoleh bahwa desa strategis di Kecamatan Tekarang adalah Desa Sempadian dan Desa Sari Makmur. Kedua desa ini menjadi desa strategis karena berdampingan dengan desa lain lebih banyak dibandingkan desa lainnya. Oleh karena Desa Sempadian dan Desa Sari Makmur merupakan dua desa yang bertetangga, maka dalam pewarnaannya diwarnai dengan warna yang berbeda.

\section{PENUTUP}

Berdasarkan pada pembahasan yang dilakukan, diperoleh kesimpulan sebagai berikut:

Jumlah derajat (degree) pada setiap simpul, sisi, dan secara tidak langsung juga untuk pewarnaan wilayah pada graf menentukan bilangan kromatik yang menentukan jumlah minimum warna yang akan mewarnai graf. Algoritma penyelesaian yang dapat digunakan pada pewarnaan graf adalah Algoritma Welch-Powell. Algoritma Welch-Powell merupakan salah satu algoritma pewarnaan graf yang melakukan pewarnaan berdasarkan derajat tertinggi dari simpul-simpulnya. Pewarnaan simpul dan pewarnaan sisi menggunakan algoritma yang sama, sedangkan pada pewarnaan wilayah, peta atau denah yang akan diwarnai, terlebih dahulu diubah menjadi graf planar, kemudian ke graf dual. Konsep 
pewarnaan pada graf dual menggunakan konsep pewarnaan simpul. Lebih lanjut, untuk penerapannya diperoleh:

1. Pada kasus pewarnaan simpul graf untuk menentukan pembagian kunci loker di kantor penjagaan babysitter, dimana terdapat 8 orang anak dengan 6 waktu penitipan yang berbeda, diperoleh bahwa minimal loker yang perlu disediakan oleh kantor adalah 5 loker yang diberikan 5 buah kuncinya kepada orangtua sesuai jadwal penitipan. Pembagian kunci loker dengan pewarnaan simpul membuat pembuatan loker lebih hemat dan lebih efektif.

2. Pada kasus pewarnaan sisi graf untuk mengefektifkan shift kerja pada sebuah pabrik reparasi mobil, diperoleh bahwa dari 8 buah mobil klien pabrik yang harus selesai direparasi dalam satu pekan, dibutuhkan paling sedikit 7 shift kerja pada 3 pos reparasi.

3. Pada kasus pewarnaan wilayah graf untuk menentukan warna peta pada Kecamatan Tekarang yang terdiri dari 7 desa diperoleh bahwa peta dapat diwarnai dengan setidaknya 3 warna. Desa Sari Makmur dan Desa Cepala diwarnai merah, Desa Matang Segarau, Desa Tekarang dan Desa Sempadian diwarnai biru, Desa Rambayan dan Desa Sempadian diwarnai ungu. Selain itu, dengan menggunakan konsep pewarnaan simpul yang dibuat dari graf dual, diperoleh bahwa desa strategis di Kecamatan Tekarang adalah Desa Sempadian dan Desa Sari Makmur, dimana kedua desa ini dapat didahulukan pembangunannya untuk mempercepat pembangunan wilayah Kecamatan Tekarang.

\section{DAFTAR PUSTAKA}

[1] Preeti, Gupta. A Study of Vertex-Edge Coloring Techniques with Application. International Journal of Core Engineering \& Management. 2014. Vol.1. 27-32

[2] Budiman, Hengky. Penerapan Graph Coloring untuk Merencanakan Jadwal. STEI ITB, Bandung. 2006.

[3] Ramadhani, Risky Aswi. Implementasi Graph Coloring dalam Pemetaan Kecamatan di Kabupaten Kediri. Jurnal Simetris. 2006. Vol. 7. 737-742

[4] Lipschutz, Seymour \& Lipson, Marc. Theory and Problems of Discrete Mathematics. United States: McGraw-Hill. 2007.

[5] Munir, R. Matematika Diskrit Ed ke-3. Bandung: Informatika Bandung; 2010.

[6] Peta Kecamatan Tekarang [Internet]. 2010. [diakses 2019 Juli 2]. Dari: https://sambas.go.id.

\begin{tabular}{|c|c|}
\hline AFRIANTINI & $\begin{array}{l}\text { : Jurusan Matematika FMIPA Untan, Pontianak } \\
\text { afriantini04@ gmail.com }\end{array}$ \\
\hline HELMI & $\begin{array}{l}\text { Jurusan Matematika FMIPA Untan, Pontianak } \\
\text { helmi132205@yahoo.co.id }\end{array}$ \\
\hline FRANSISKUS FRAN & $\begin{array}{l}\text { Jurusan Matematika FMIPA Untan, Pontianak } \\
\text { fransiskusfran@ @ath.untan.ac.id }\end{array}$ \\
\hline
\end{tabular}

